\title{
Australian Science Centre
}

Australia's combined home for scientific societies and meeting place for scientists is proving to be a valuable aid to communication.

Australia's National Science Centre, opened by the Duke of Edinburgh on May 30, 1968, has had a most successful first eighteen months. It now accommodates thirty-four scientific and technological societies, and a further twentyfour use it for conferences. The facilities of the centre are also in great demand for international, national and local meetings.

The setting up of the centre has been the special task of the Ian Clunies Ross Memorial Foundation, which aims to promote and further the development of scientific research and technology. After early proposals for the centre had been well received by Australian scientific and technological societies the foundation began raising funds. In order to take advantage of promised donations from industry and commerce an amendment to the Income Tax Act had to be approved by Parliament so that donations could be assessed as non-taxable. After this, national and state appeal committees were set up.

The immediate response was approximately $\$ 564,000$ (Australian), subsequently increased by personal approaches and interest earned on investment to $\$ 960,000$. Land was purchased close to the University of Melbourne, with ready access from all areas and where car parking was reasonably easy and likely to remain so for some time. The planning of the building was put in the hands of the project management service and the design and construction experts of Civil and Civic Pty. Ltd. 'The foundation also invited several specialized societies to appoint small advisory committees which gave advice on closed circuit television, projection facilities, illumination, air conditioning and so on. The CSIRO also provided specialized advice on soil mechanics, acoustics and the selection of timber.

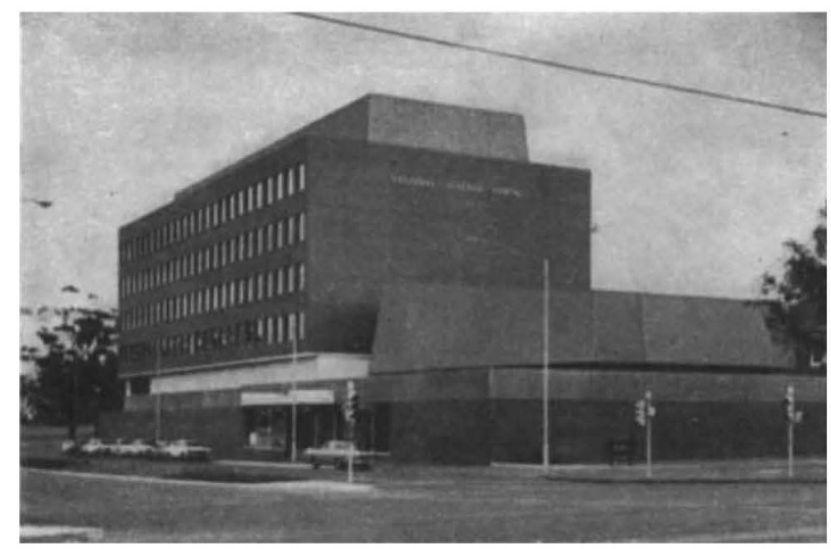

General view of Australian National Science Centre.

As completed, the main building-Clunies Ross House, shown in the photograph - is a concrete and steol structure clad chiefly with red manganese bricks. It is linked to the auditorium block by a continuous series of precast concrete fluted slabs, outside which is a brick wall. In the main building this wall sereens off the car park and in the auditorium block it serves to reflect and absorb sound from passing traffic. The main block has six floors; the ground floor with banking facilities, a kiosk for travel arrangements, and parking space for fifty-six cars.

The first floor accommodates the Scionces Club. This already has 1,500 members, and a kitchen equipped to serve up to five hundred meals at a time. The club aims to foster informal meetings and discussion between members of the various societies accredited to the centre. Temporary membership is available to visiting scientists and technologists and to those from other states and overscas attending conferences in the building. The club is wired to receive closed circuit television from the conference rooms, and is completcly sound proofed from the rest of the building.

Above the club is 37,200 square feet of office accommodation. The roof houses the mechanical plant and storage space, most of which is available to societies to store their records. The conference area has an auditorium which seats five hundred, and can also be used as a display centre. It can also be converted into three separate conference rooms holding two hundred and twenty, ninety and ninety people. A suspended projection and control room serves all three rooms. A fourth conference room holding about a hundred people is wired for closed circuit television from the main conference room. The largest of the four committee rooms holds up to fifty people and can be used for small seminars or symposia.

The success of the centre is no doubt due in part to the wisdom of its governors, who decided that before a society can use the facilities offered it must be accredited. Basically this ensures that the society is of good standing and actively involved in promoting science and technology. Each accredited society can request office space, for which it contributes according to the area occupied. This contribution is much less per square foot than a commercial tonant pays in rent.

Each accredited society, whether using office space or not, is granted full use of a conference room and a committee room ten times a year free of charge. Supper room facilities are provided free, but a small charge is made for projection room facilities to cover maintenance costs. If a society has more than ten meetings in a year a small charge is made for the rest.

Several groups of societies, some with similar interests, share office, sccretarial staff and telephone. Societies without office accommodation or with no telephone are encouraged to enter their name in the telephone directory, using the number of the foundation, which acts as a liaison office in accepting letters or calls, transmitting requests and providing general information. The only charge is nominal and made by the postal authorities to cover the cost of the printed entry.

After a successful beginning for the centre there is much to be done. Similar facilities are needed in cach of the other state capitals of Australia. Closer cooperation between societies needs to be made possible through, for example, simplified joint membership records and publication and other office procedures, and, more ambitiously, the foundation feels that the National Science Centre has a part to play in fostering a better appreciation of seience and technology by the Australian public. 